\title{
Persistence of HPV infection and risk of high-grade cervical intraepithelial neoplasia in a cohort of Colombian women
}

\author{
N Muñoz', G Hernandez-Suarez*,1, F Méndez',2, M Molano', H Posso', V Moreno³, R Murillo', M Ronderos', \\ C Meijer ${ }^{4}$ and Á Muñoz ${ }^{5}$ for the INC HPV Study Group \\ 'Subdirección de Investigaciones y Salud Publica, Instituto Nacional de Cancerología, Bogotá, Colombia; 'Escuela de Salud Pública, Universidad del Valle, \\ Cali, Colombia; ${ }^{3}$ Cancer Epidemiology Service, Instituto Catalán de Oncología, Barcelona, Spain; ${ }^{4}$ Department of Pathology, Vrije Universiteit Medical \\ Center, Amsterdam, The Netherlands; ${ }^{5}$ Department of Epidemiology, Johns Hopkins Bloomberg School of Public Health, Baltimore, MD, USA
}

Cervical human papillomavirus (HPV) infection is the necessary, but not a sufficient, cause of cervical cancer (Walboomers et al, 1999; Muñoz et al, 2003). Only a small fraction of those with persistent HPV infections develop cervical cancer and its immediate precursors (Schiffman and Kjaer, 2003). Although persistent HPV infection has been considered a prerequisite for cervical cancer (Bosch et al, 2008), there is no consensus on its definition. Most investigators define it as detection of the same HPV type or group of types on two consecutive visits, but these could be from 4 months up to 5-7 years apart (Schiffman and Kjaer, 2003; Castle et al, 2005). A recent review of problems with this approach suggests restricting analyses to incident infections, and considering the duration of the infection rather than the number of positive tests (Woodman et al, 2007). Agreement on definition will facilitate comparisons of results from studies, on end points in vaccine trials and screening policy recommendations. Some recent reports cast doubts on the need for persistence for progression to high-grade squamous intraepithelial lesions (HSIL) or intraepithelial neoplasia (CIN2/3) (Schiffman et al, 2005; Winer et al, 2005). Moreover, most cohort studies of cervical HPV infections have been in young women (Ho et al, 1998; Moscicki et al, 2001; Woodman et al, 2001; Brown et al, 2005; Winer et al,

*Correspondence: Dr G Hernandez-Suarez, Instituto Nacional de Cancerología, Av I No 9-85 Tercer piso, Grupo de Investigación epidemiológica, Bogotá, Colombia; E-mail: gahernandez@cancer.gov.co Received 16 January 2009; revised 9 February 2009; accepted 16 February 2009; published online 17 March 2009
2005), one suggesting that HSIL is often an early manifestation of HPV infection in young women (Winer et al, 2005). We present results on clearance of HPV incident infection and its determinants and estimate the risk of progression to CIN2/3 in a cohort of young and older Colombian women followed at regular scheduled visits. We propose a new definition of persistence based on duration of infection, and compare it with the traditional definition based on detection of HPV DNA in two consecutive visits.

\section{MATERIALS AND METHODS}

Between November 1993 and November 1995, the National Cancer Institute of Colombia (INC) invited 2200 women aged $15-85$ years to participate in a prospective study (Molano et al, 2002a), previously approved by the INC ethics committee. All study participants signed an informed consent form in compliance with the clinical research guidelines. The 2200 women were randomly selected from four low-income health districts of Bogotá who had consulted cervical cancer screening centres or family planning clinics. Methods of recruitment and data collection have been described elsewhere (Molano et al, 2002a,b). Briefly, eligible women were those residing in Bogotá, without history of cervical neoplasia, conisation or hysterectomy, willing to participate and who signed an informed consent form. At study entry, participants responded to a questionnaire on risk factors for cervical cancer and underwent a pelvic examination with collection of cervical cells for cytology and HPV detection. Follow-up visits were 
scheduled every 6 months until March 2004. At each visit, a questionnaire on lifestyle and sexual behaviour was used, a pelvic examination was performed and cervical specimens were collected using Ayre spatulas and endocervical brushes for cytology and HPV detection. The specimens were eluted in phosphate-buffered saline $+0.05 \%$ thiomersal. Colposcopic examination was performed in all women with repeated diagnosis of low-grade squamous intraepithelial lesions (LSIL) or with cytological evidence of HSIL. Colposcopically guided cervical biopsies were performed in women with cytological or colposcopic evidence of HSIL.

From the 2200 women invited to participate, 53 (2.4\%) refused and $8(0.4 \%)$ were ineligible (due to mental illness, hysterectomy or history of cervical cancer) leaving 2139 women. For this analysis, we only included women with normal Pap smear results and a valid HPV DNA sample at baseline with at least two visits during follow-up. If DNA results were not available for the first visit (because no scrape was available or due to failure to amplify the $\beta$-globin gene), the second visit was used as baseline.

Human papillomavirus presence and type was assessed by Southern blot hybridisation of GP5 +/bioGP6 + PCR products using a general probe of specific DNA fragments from cloned DNA of six HPV types, and by the GP5 + /GP6 + PCR enzyme immunoassay (PCR-EIA) as previously described (Jacobs et al, 1997; Molano et al, 2002a). For the EIA, HPV-positive samples were first subjected to a group-specific analysis using cocktail probes for high-risk (HR) and low-risk (LR) HPVs before individual typing was performed. The HR cocktail probe consisted of oligoprobes for HPV16, 18, 31, 33, 35, 39, 45, 51, 52, 56, 58, 59, 66 and 68; the LR HPV probe consisted of oligoprobes for HPV6, $11,26,34,40,42,43,44,53,54,55,57,61,70,71,72,73,81,82$ (MM4 and IS39 subtype), 83, 84 and CP6108. Types 73, 82, 26 and 53 were classified as HR (Muñoz et al, 2003). During follow-up, GP5 + /GP6 + PCR reverse line blot (PCR-RLB) analysis was validated and used to type the 37 different HPV types detected by PCR-EIA (van den Brule et al, 2002). In this validation process, some samples from our cohort were tested using both techniques and $96 \%$ agreement was observed between the PCR-RLB analysis and the PCR-EIA assay. Specimens from the first four visits were typed with PCR-EIA and those from subsequent visits were typed with PCR-RLB. PCR-EIA was used to assess viral load in all visits. This is a semiquantitative method based on the linear relationship between the amount of DNA and the optical density (OD) in the range of $10-10^{6}$ genome equivalents (Jacobs et al, 1997).

Pap smears were read by a cytotechnologist and classified as normal, atypical cells, HPV, mild, moderate and severe dysplasia, cancer in situ and invasive cancer. All abnormal smears as well as a $10 \%$ sample of normal smears were reviewed by two expert cytopathologists who re-classified the cytological diagnosis using the Bethesda system as normal, atypical squamous cells of undetermined significance, atypical glandular cells and LSIL or HSIL (Luff, 1992). The same pathologists read the biopsies and classified them as normal, cervicitis, cervical intraepithelial neoplasia (CIN) grade 1, 2, 3, carcinoma in situ or invasive cervical cancer.

\section{Statistical analysis}

The outcomes of interest for this analysis were clearance, duration of incident type-specific HPV infections and incidence of CIN2/3 among women with normal cytology at enrolment. An incident type-specific HPV infection was defined as the first positive typespecific result after a negative result for the same HPV type. Correspondingly, type-specific HPV clearance was defined as the first negative PCR result after an incident infection. Duration of an HPV incident infection was defined as the elapsed time from the date of infection to the date of clearance, assuming both events occurred at the mid point between consecutive visits with different
HPV status (i.e. negative to positive or positive to negative). Because women could have one or more HPV infections during follow-up, HPV type-specific infections, instead of individuals, were the unit of analysis. HPV infections were categorised using phylogenetic (de Villiers et al, 2004) and epidemiological classifications (Muñoz et al, 2003) in six groups as follows: HPV16, HPV18, $\alpha-9$ HPV types other than HPV16 (i.e. HPV31, 33, $35,52,58,67$ ), $\alpha-7$ HPV types other than HPV18 (i.e. HPV39, 45, $68,70)$, other HPV-HR types and LR HPV types.

In the analysis of clearance and duration of infection, we censored women lost to follow-up after an incident infection and those with a gap longer than 36 months between consecutive visits because the most HPV infections clear within this time (Insinga, 2007). Also, women were censored if CIN $2 / 3$ was diagnosed.

Cox regression was used to evaluate factors potentially associated with clearance, including viral load, co-infection, age at infection, previous infection during follow-up, sexual behaviour, parity and tobacco use. Viral load was included in the analysis as the maximum viral load attained during an incident infection for each defined viral group. Because there is no consensus on reference values of ODs to classify viral load, they were categorised in quintiles. The Kaplan-Meier method was used to estimate the median duration of infection for most HPV types and for each of the previously defined viral groups. Infections were considered persistent if duration was above the median.

End points of interest for the CIN2/3 analysis included histology confirmed CIN2 (9), CIN3 or carcinoma in situ (14), invasive carcinoma (3) and cases of HSIL without histology confirmation (6). The latter group was included because of the high specificity of Pap smear and the low sensitivity of one colposcopically directed biopsy. A recent report indicates that one colposcopically directed biopsy misses at least one-third of CIN3 + (Gage et al, 2006).

To evaluate the association of our proposed definition of persistent infection with the risk of CIN2/3 development we carried out a Cox regression analysis adjusting for relevant cofactors of HPV infection (i.e. age, parity, OC use, smoking status and co-infection). Alternatively, we also used a longitudinal approach grouping all possible triplets of consecutive visits by individual to compare the results of the new approach with those obtained using the traditional definition of persistence (ie two consecutive positive visits) (Zeger and Liang, 1986). Specifically, HPV type-specific status was assessed at the first two visits of every triplet and classified as: (1) negative at both, (2) positive at either or (3) positive at both visits. Women should have normal cytology at the first visit of the triplet and lesion progression was assessed in the third. Here the time lag between visits was not restricted and logistic regression analysis was carried out using generalised estimating equations to account for the correlation between triplets of visits contributed by the same individual (Zeger and Liang, 1986). In both approaches, we considered incident and prevalent HPV infections and we adjusted for the same HPV cofactors.

\section{RESULTS}

Of the 2139 women who agreed to participate in the cohort study, 261 had only one visit during follow-up and 150 had abnormal cytology at baseline leaving $1728(80 \%)$ women eligible for this analysis (154 included based on data from the second visit). This group represented 12526 follow-up visits with cervical scrapes tested for HPV DNA.

The prevalence of HPV infection at baseline was $13.4 \%$ (224). During follow-up, 253 and 209 women HPV DNA negative at baseline developed single and multiple incident HPV type infections, respectively. In addition, 110 women who were HPV DNA positive at baseline developed incident infections (i.e. infections with a different HPV type) during follow-up. 
Table I Factors associated with clearance of incident infection by HPV types in women with normal cytology at baseline

\begin{tabular}{|c|c|c|c|c|c|c|c|c|c|c|c|c|c|c|c|c|c|c|c|c|c|c|c|c|}
\hline \multirow{4}{*}{$\begin{array}{l}\text { HPV Type } \\
\text { Women with incident } \\
\text { infections } \\
\text { Incident infection } \\
\text { excluded from analysis }\end{array}$} & \multicolumn{4}{|c|}{ HPVI6 } & \multicolumn{4}{|c|}{ SP 9 other than 16} & \multicolumn{4}{|c|}{ HPVI8 } & \multicolumn{4}{|c|}{ SP 7 other than 18} & \multicolumn{4}{|c|}{ Other high-risk HPV } & \multicolumn{4}{|c|}{ Low-risk HPV } \\
\hline & \multicolumn{4}{|c|}{124} & \multicolumn{4}{|c|}{176} & \multicolumn{4}{|c|}{55} & \multicolumn{4}{|c|}{137} & \multicolumn{4}{|c|}{164} & \multicolumn{4}{|c|}{216} \\
\hline & \multicolumn{4}{|c|}{8} & \multicolumn{4}{|c|}{13} & \multicolumn{4}{|c|}{7} & \multicolumn{4}{|c|}{6} & & & 13 & & & & 17 & \\
\hline & $\begin{array}{l}\text { No. of } \\
\text { women }\end{array}$ & $\begin{array}{l}\text { No. of } \\
\text { events }\end{array}$ & $\mathrm{HR}$ & $(95 \% \mathrm{Cl})$ & $\begin{array}{l}\text { No. of } \\
\text { women }\end{array}$ & $\begin{array}{l}\text { No. of } \\
\text { events }\end{array}$ & HR & $(95 \% \mathrm{Cl})$ & $\begin{array}{l}\text { No. of } \\
\text { women }\end{array}$ & $\begin{array}{l}\text { No. of } \\
\text { events }\end{array}$ & HR & $(95 \% \mathrm{Cl})$ & $\begin{array}{l}\text { No. of } \\
\text { women }\end{array}$ & $\begin{array}{l}\text { No. of } \\
\text { events }\end{array}$ & HR & $(95 \% \mathrm{Cl})$ & $\begin{array}{l}\text { No. of } \\
\text { women }\end{array}$ & $\begin{array}{l}\text { No. of } \\
\text { events }\end{array}$ & HR & $(95 \% \mathrm{Cl})$ & $\begin{array}{l}\text { No. of } \\
\text { women }\end{array}$ & $\begin{array}{l}\text { No. of } \\
\text { events }\end{array}$ & HR & $(95 \% \mathrm{Cl})$ \\
\hline Co-infection & & & & & & & & & & & & & & & & & & & & & & & & \\
\hline No & 63 & 51 & 1 & & 84 & 69 & 1 & & 17 & 15 & 1 & & 56 & 49 & 1 & & 78 & 62 & 1 & & 82 & 67 & 1 & \\
\hline Yes & 53 & 45 & 0.98 & $(0.62-1.55)$ & 79 & 67 & 0.83 & $(0.56-1.22)$ & 31 & 24 & 0.50 & $(0.22-1.15)$ & 75 & 62 & 1.04 & $(0.69-1.56)$ & 73 & 57 & 1.01 & $(0.68-1.50)$ & 117 & 89 & 0.87 & $(0.62-1.21)$ \\
\hline $\begin{array}{l}\text { Previous infection by other } \\
\text { HPV type }\end{array}$ & & & & & & & & & & & & & & & & & & & & & & & & \\
\hline No & 82 & 71 & 1 & & 117 & 101 & 1.00 & & 27 & 22 & 1 & & 82 & 74 & 1 & & 96 & 82 & 1 & & 128 & 109 & 1 & \\
\hline Yes & 34 & 25 & 1.07 & $(0.61-1.88)$ & 46 & 35 & 0.95 & $(0.62-1.45)$ & 21 & 17 & 1.24 & $(0.52-2.97)$ & 49 & 37 & 0.98 & $(0.63-1.54)$ & 55 & 37 & 0.71 & $(0.46-1.11)$ & 71 & 47 & 0.71 & $(0.49-1.03)$ \\
\hline Viral load (quintile) & & & & & & & & & & & & & & & & & & & & & & & & \\
\hline I lowest & 22 & 19 & 1 & & 33 & 30 & 1 & & 7 & 5 & 1 & & 25 & 23 & 1 & & 32 & 25 & 1 & & 77 & 63 & 1 & \\
\hline$\|$ & 24 & 21 & 0.56 & $(0.27-1.16)$ & 32 & 29 & 0.74 & $(0.42-1.29)$ & 11 & 11 & 0.84 & $(0.20-3.43)$ & 29 & 28 & 0.62 & $(0.35-1.11)$ & 28 & 25 & 0.97 & $(0.52-1.79)$ & 47 & 40 & 0.86 & $(0.56-1.30)$ \\
\hline III & 31 & 27 & 0.29 & $(0.14-0.58)$ & 32 & 27 & 0.56 & $(0.32-0.98)$ & 9 & 9 & 0.60 & $(0.11-3.27)$ & 29 & 24 & 0.47 & $(0.25-0.90)$ & 30 & 23 & 0.78 & $(0.42-1.45)$ & 27 & 19 & 0.51 & $(0.29-0.89)$ \\
\hline IV & 19 & 15 & 0.20 & $(0.09-0.47)$ & 32 & 27 & 0.43 & $(0.24-0.77)$ & 11 & 9 & 0.52 & $(0.09-2.90)$ & 24 & 21 & 0.30 & $(0.15-0.58)$ & 28 & 26 & 0.61 & $(0.33-1.124)$ & 17 & 14 & 0.39 & $(0.21-0.72)$ \\
\hline $\mathrm{v}$ & 20 & 14 & 0.19 & $(0.09-0.42)$ & 34 & 23 & 0.32 & $(0.17-0.60)$ & 10 & 5 & 0.05 & $(0.01-0.29)$ & 24 & 15 & 0.20 & $(0.10-0.42)$ & 33 & 20 & 0.28 & $(0.14-0.58)$ & 31 & 20 & 0.31 & $(0.18-0.55)$ \\
\hline Age (years) & & & & & & & & & & & & & & & & & & & & & & & & \\
\hline$<30$ & 41 & 31 & 1 & & 67 & 54 & 1 & & 15 & 12 & 1 & & 42 & 36 & 1 & & 61 & 48 & 1 & & 61 & 50 & 1 & \\
\hline$\geqslant 30$ & 75 & 65 & 1.03 & $(0.53-1.99)$ & 96 & 82 & 0.87 & $(0.53-1.42)$ & 33 & 27 & 0.97 & $(0.32-2.94)$ & 89 & 75 & 1.29 & $(0.69-2.39)$ & 90 & 71 & 1.71 & $(1.01-2.90)$ & 138 & 106 & 0.79 & $(0.49-1.27)$ \\
\hline Panity & & & & & & & & & & & & & & & & & & & & & & & & \\
\hline $0-1$ & 37 & 28 & 1 & & 58 & 49 & 1 & & 3 & 3 & 1 & & 41 & 35 & 1 & & 59 & 47 & 1 & & 66 & 51 & 1 & \\
\hline $2-3$ & 60 & 51 & 1.15 & $(0.60-2.18$ & 79 & 64 & 1.38 & $(0.86-2.20)$ & 28 & 22 & 0.45 & $(0.06-3.54)$ & 65 & 59 & 1.61 & $(0.90-2.89)$ & 64 & 54 & 1.25 & $(0.786-1.98)$ & 100 & 77 & 1.20 & $(0.79-1.82)$ \\
\hline$>3$ & 18 & 16 & 0.99 & $(0.43-2.28$ & 26 & 23 & 1.28 & $(0.68-2.42)$ & 17 & 14 & 0.31 & $(0.02-3.99)$ & 24 & 16 & 1.20 & $(0.55-2.59)$ & 28 & 18 & 0.67 & $(0.35-1.31)$ & 33 & 28 & 1.13 & $(0.60-2.13)$ \\
\hline Oral contraceptives & & & & & & & & & & & & & & & & & & & & & & & & \\
\hline Never & 63 & 53 & 1 & & 90 & 78 & 1 & & 23 & 17 & 1 & & 72 & 60 & 1 & & 78 & 58 & 1 & & 103 & 83 & 1 & \\
\hline Ever & 53 & 43 & 1.03 & $(0.65-1.64)$ & 73 & 58 & 0.71 & $(0.48-1.05)$ & 25 & 22 & 1.03 & $(0.40-2.63)$ & 59 & 51 & 0.99 & $(0.64-1.54)$ & 73 & 61 & 0.65 & $(0.42-0.99)$ & 96 & 73 & 0.90 & $(0.64-1.25)$ \\
\hline Intrauterine device & & & & & & & & & & & & & & & & & & & & & & & & \\
\hline Never & 47 & 35 & 1 & & 57 & 50 & 1 & & 18 & 15 & 1 & & 53 & 43 & 1 & & 63 & 54 & 1 & & 89 & 69 & 1 & \\
\hline Ever & 69 & 61 & 0.99 & $(0.60-1.63)$ & 106 & 86 & 0.93 & $(0.61-1.40)$ & 30 & 24 & 2.37 & $(0.98-5.71)$ & 78 & 68 & 1.04 & $(0.66-1.63)$ & 88 & 65 & 0.79 & $(0.52-1.18)$ & 110 & 87 & 1.17 & $(0.81-1.67)$ \\
\hline $\begin{array}{l}\text { New sex partners in past } \\
6 \text { months }\end{array}$ & & & & & & & & & & & & & & & & & & & & & & & & \\
\hline No & 105 & 86 & 1 & & 142 & 121 & 1.00 & & 45 & 36 & 1 & & 116 & 98 & 1 & & 133 & 105 & 1 & & 183 & 142 & 1 & \\
\hline Yes & 11 & 10 & 0.36 & $(0.08-1.58)$ & 20 & 14 & 0.67 & $(0.36-1.26)$ & 3 & 3 & 0.49 & $(0.11-2.21)$ & 14 & 12 & 0.64 & $(0.26-1.58)$ & 18 & 14 & 0.74 & $(0.38-1.45)$ & 14 & 12 & 1.16 & $(0.57-2.36)$ \\
\hline Age at first intercourse & & & & & & & & & & & & & & & & & & & & & & & & \\
\hline$<17$ & 34 & 24 & 1 & & 63 & 49 & 1 & & 15 & 11 & 1 & & 39 & 30 & 1 & & 61 & 47 & 1 & & 61 & 48 & 1 & \\
\hline $\mid 7-21$ & 62 & 56 & 1.43 & $(0.74-2.77)$ & 79 & 70 & 1.22 & $(0.81-1.84)$ & 20 & 16 & 1.15 & $(0.40-3.23)$ & 64 & 56 & 0.73 & $(0.42-1.26)$ & 68 & 52 & 0.89 & $(0.56-1.40)$ & 97 & 74 & 1.06 & $(0.68-1.64)$ \\
\hline$\geqslant 22$ & 19 & 15 & 1.18 & $(0.48-2.92)$ & 21 & 17 & 1.77 & $(0.93-3.38)$ & 13 & 12 & 1.34 & $(0.32-5.54)$ & 27 & 24 & 0.61 & $(0.28-1.32)$ & 22 & 20 & 0.84 & $(0.43-1.65)$ & 41 & 34 & 1.30 & $(0.74-2.30)$ \\
\hline Smoking & & & & & & & & & & & & & & & & & & & & & & & & \\
\hline Never & 73 & 62 & 1 & & 110 & 91 & 1.00 & & 33 & 26 & 1 & & 92 & 76 & 1 & & 96 & 76 & 1 & & 136 & 107 & 1 & \\
\hline Ever & 43 & 34 & 0.69 & $(0.43-1.10$ & 53 & 45 & 1.36 & $(0.91-2.05)$ & 15 & 13 & 0.57 & $(0.23-1.44)$ & 39 & 35 & 0.75 & $(0.47-1.20)$ & 55 & 43 & 0.99 & $(0.67-1.48)$ & 63 & 49 & 0.84 & $(0.56-1.25)$ \\
\hline
\end{tabular}


Thus, a total of 572 women developed 872 type-specific incident HPV infections during follow-up; 64 infections were excluded from the analysis because the interval between consecutive visits was longer than 36 months or got no further visits after the infection (Table 1). Median interval between visits was 6.6 months (interquartile range, IQR: 6.0-9.2), median duration of follow-up for clearance analysis was 6.4 years (IQR: 3.7-8.5 years) and median duration of total follow-up was 8.9 years (IQR: 6.3-9.4 years).

Maximum viral load attained during follow-up ranged from 0.18 to $4.07 \mathrm{OD}$. The IQR was similar among HR HPV types groups, with a median of $1.8-2.0 \mathrm{OD}$, whereas the median was lower in the LR HPV group (0.8 OD).

Cox regression analysis including all relevant cofactors for HPV infection shows that clearance of incident infections by HPV types is inversely associated with viral load (Table 1). The likelihood of clearance was significantly reduced for infections with higher viral load for all HPV groups $(P$-value for trend $<0.001)$. With the exception of use of an intrauterine device that doubled the chance of clearance for HPV18 infections and age older than 30 years that increased $70 \%$ the probability of clearance of 'other HR HPV', none of the factors affected the likelihood of clearance. For all HPV groups, except HPV16, clearance was similar in women under 30 years of age and in women aged 30 years or older. Although no apparent differences in the probability of clearance between HPV groups were observed (Figure 1), difference of clearance with age in HPV16 infection (log-rank test $P<0.01$ ) was lost in the adjusted analysis (Table 1).

Median duration of HPV incident infection seemed higher for HR HPV types than for LR types (Figure 1), but confidence intervals (CI) between types and between age groups had substantial overlap, except for HPV16 for which younger women had significantly longer persistence of infection. Although virtually all infections with lowest viral loads were cleared by the second year of follow-up, those with viral load in the highest quintile persisted longer. However, after 5 years of follow-up most of the infections have cleared (Figure 2).

Among women with normal cytology at baseline, $32 \mathrm{CIN} 2 / 3$ / HSIL incident cases were diagnosed during follow-up $(0.23$ per 100 person-years; 95\% CI 0.16-0.33). Incident HPV infections occurring in women under age 30 carry a risk of CIN2/3 similar to that of incident infections occurring later $(<30$ : 0.025 per 100 person-years, 95\% CI $0.015-0.042$; $\geqslant 30$ : 0.023 , 95\% CI $0.014-$ $0.037)$. Most cases $(n=25)$ were associated with HPV16 and other types from the $\alpha-9$ group. For HPV16, only those infections that lasted more than the median duration were associated with an increased risk of CIN2/3/HSIL, compared with no HPV16 infection, and this occurred in both age strata $(<30$ and $\geqslant 30)$. The two cases of CIN $2 / 3$ that occurred after infection of short duration were diagnosed in the second visit.

For $\alpha-9$ other than 16, infections lasting less than the median, as well as those lasting more, were associated with an increased risk of CIN2/3/HSIL (Table 2); this also applied in the analysis based on triplets. Risk of $\mathrm{CIN} 2 / 3$ was higher for HR HPV types at two consecutive visits than for infections positive at only one visit; no significant association was observed for LR types. For HPV16 the increased risk was particularly marked when women were positive in two consecutive visits and it was also increased, but not significantly, when women were positive in only one visit. For $\alpha-9$ other than 16, an increased risk was observed for women positive at one of the two consecutive visits, as well as at the two consecutive visits. Median time between the first two visits was similar for all HPV group infections (7.5 months) (Table 3 ).

\section{DISCUSSION}

Understanding the natural history of HPV infection and the resulting cervical lesions requires long-term follow-up studies in which cervical cells and risk factor information are collected at
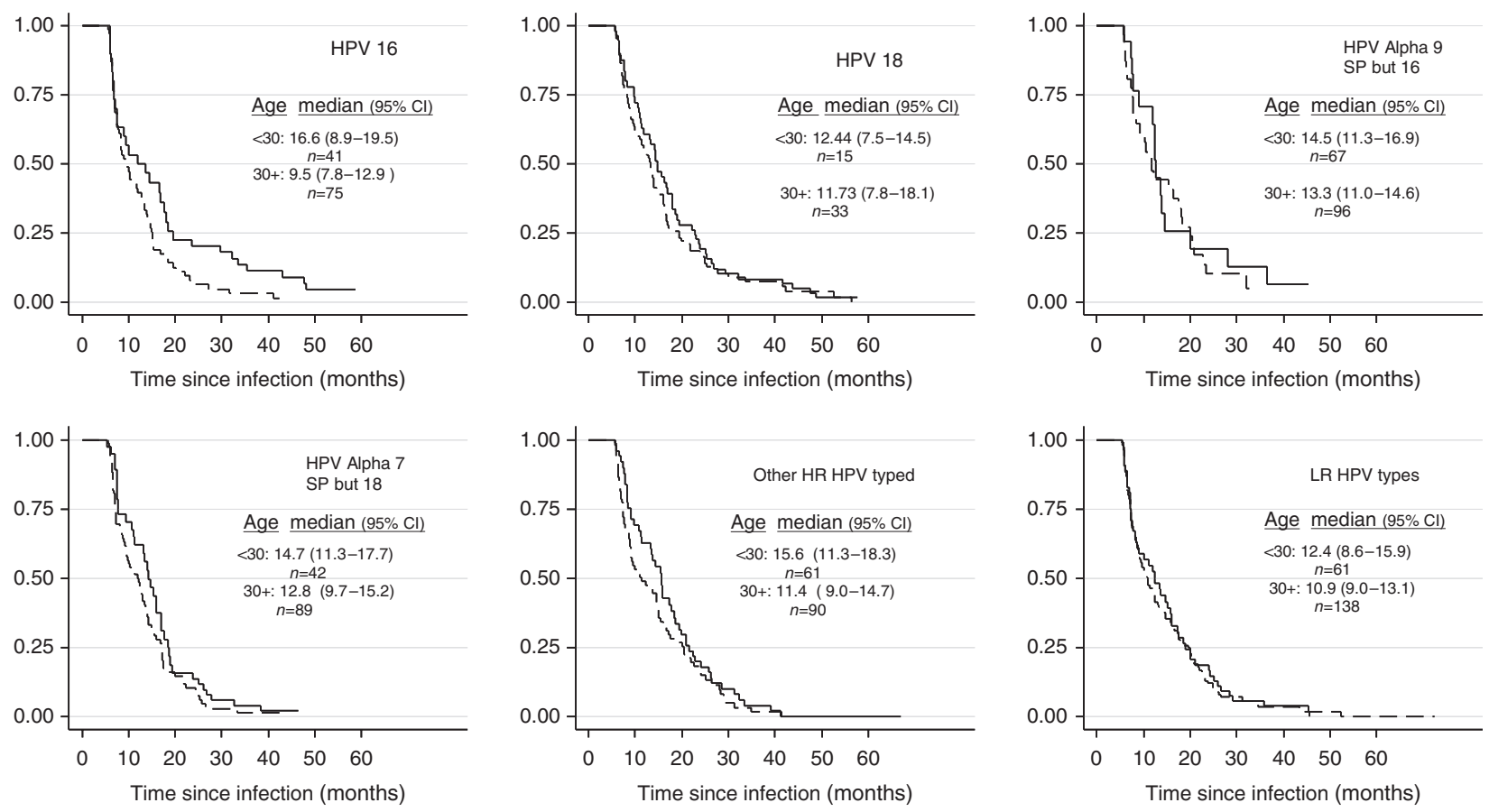

$-<30 \quad-----30+$

Figure I Cumulative probability of clearance of incident HPV infection, by viral group and age group (under 30 years and 30 years and over), in women with normal cytology at baseline. Number of infections (n) with point estimates and $95 \% \mathrm{Cl}$ of median duration of infection by age group are reported. HPVI 6 persisted significantly longer in women under 30 years of age than older women $(P<0.01$, log-rank test). 
1188
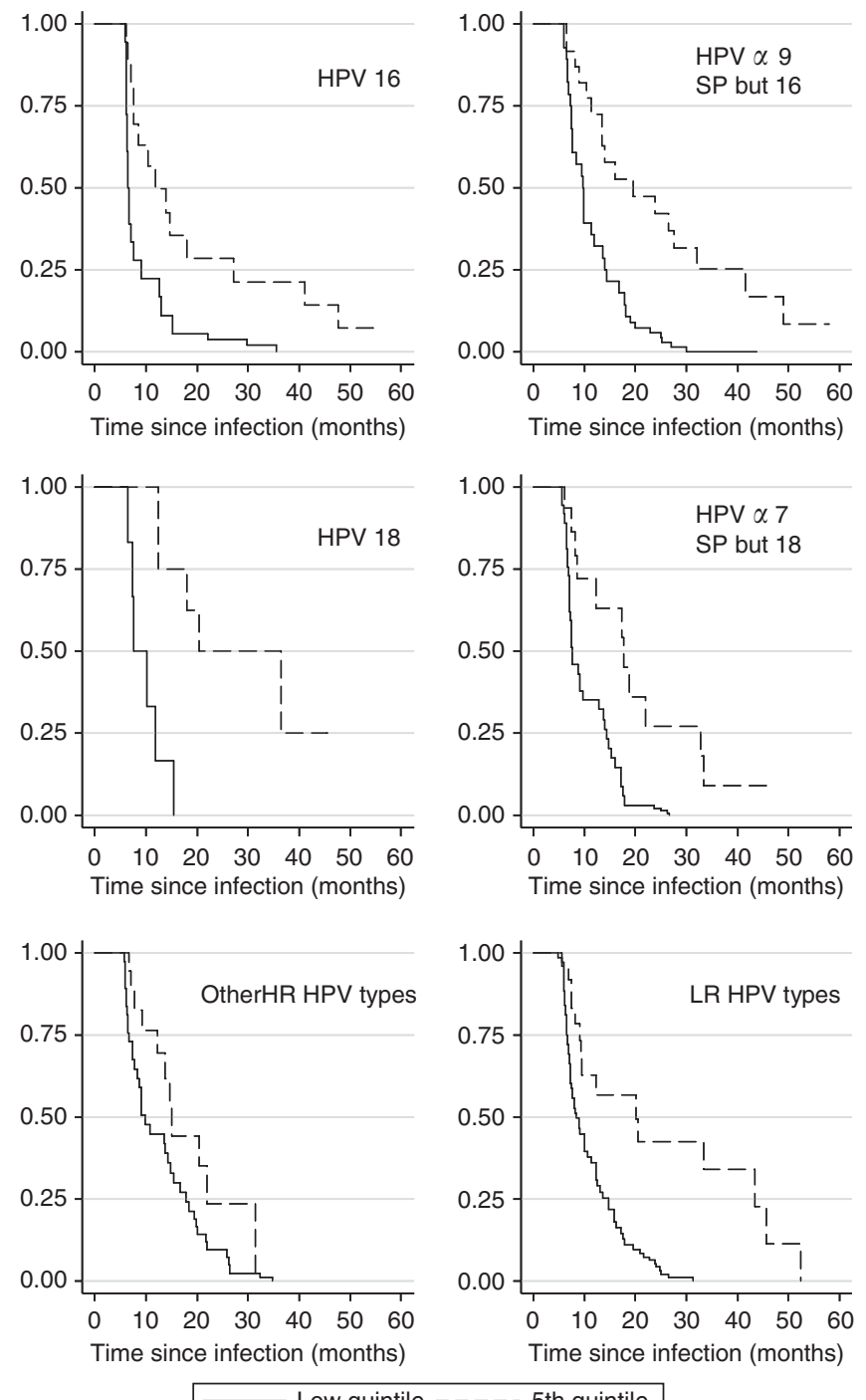

$$
\text { - Low quintile ----- 5th quintile }
$$

Figure 2 Cumulative probability of clearance of incident HPV infections by viral load (lower and fifth quintile) and viral group, in women with normal cytology at baseline. Viral load was estimated from the optical density and values categorised in quintiles.

Table 2 Risk and HR of high-grade cervical dysplasia (CIN2/3/HSIL) by duration of HPV infection

\begin{tabular}{lccccc}
\hline Viral type & $\begin{array}{c}\text { Median } \\
\text { duration } \\
\text { (month) }\end{array}$ & Cases $^{\mathbf{a}}$ & $\begin{array}{c}\text { Rate } \\
\text { (per 100) }\end{array}$ & HR* $^{*}$ & $\mathbf{( 9 5 \% ~ C l )}$ \\
\hline HPVI6 & Negative & 17 & 0.15 & 1 & \\
& $<10.83$ & 2 & 0.49 & 3.59 & $(0.82-15.70)$ \\
& $\geqslant 10.83$ & 12 & 2.24 & 19.51 & $(9.07-42.00)$ \\
HPV $\alpha$-9 SP but 16 & Negative & 20 & 0.18 & 1 & \\
& $<13.79$ & 6 & 0.94 & 5.38 & $(2.58-11.22)$ \\
& $\geqslant 13.79$ & 5 & 0.77 & 3.12 & $(1.19-8.18)$ \\
\hline
\end{tabular}

${ }^{a}$ One case excluded as duration of infection could not be computed. *Adjusted for age, parity, smoking status, oral contraceptive use, and HPV co-infection. HPV = human papillomavirus.

frequent intervals to monitor HPV status and appearance of cervical lesions. Most studies (Ho et al, 1998; Moscicki et al, 2001; Woodman et al, 2001; Brown et al, 2005; Winer et al, 2005) include
Table 3 Risk of high-grade cervical dysplasia (CIN2/3/HSIL) by number of HPV-positive visits

\begin{tabular}{|c|c|c|c|c|}
\hline \multirow[b]{2}{*}{ HPV status } & \multicolumn{2}{|c|}{ Triplets $^{\mathrm{a}}$} & \multirow[b]{2}{*}{ Adjusted $\mathbf{O} \mathbf{R}^{\mathbf{b}}$} & \multirow[b]{2}{*}{$(95 \% \mathrm{Cl})$} \\
\hline & Cases & Control & & \\
\hline \multicolumn{5}{|l|}{ HPVI6 } \\
\hline Negative at both & 6 & 8.121 & 1 & \\
\hline Positive at either & 2 & 229 & 6.13 & $(0.56-66.55)$ \\
\hline Positive at both & 7 & 75 & 193.46 & $(46.49-805.09)$ \\
\hline \multicolumn{5}{|l|}{$\alpha-9$ other HPVI6 } \\
\hline Negative at both & 10 & 8.014 & 1 & \\
\hline Positive at either & 2 & 334 & $13.5 \mid$ & $(2.39-76.28)$ \\
\hline Positive at both & 2 & 95 & 48.31 & $(7.75-301.02)$ \\
\hline \multicolumn{5}{|l|}{ Any high-risk HPV } \\
\hline Negative at both & I & 7.241 & I & \\
\hline Positive at either & 5 & 915 & 23.43 & $(2.24-244.70)$ \\
\hline Positive at both & 10 & 351 & 168.66 & $(17.84-1594.27)$ \\
\hline \multicolumn{5}{|l|}{ Any low-risk HPV } \\
\hline Negative at both & 12 & 7.876 & 1 & \\
\hline Positive at either & 2 & 454 & 0.62 & $(0.06-6.11)$ \\
\hline Positive at both & 1 & 111 & 2.29 & $(0.26-20.16)$ \\
\hline
\end{tabular}

${ }^{\mathrm{a} F r o m} 1539$ clusters (women). ${ }^{\mathrm{b}}$ Adjusting for parity, age, oral contraceptives and smoking, co-infection and clustering. HPV = human papillomavirus.

young women from populations at LR for cervical cancer and do not discriminate incident from prevalent infections in the analysis. Our study was conducted in a population at HR of cervical cancer, including young and older women, where incident HPV infections were considered separately. A high prevalence and incidence of cervical HPV infection has been reported in this cohort (Molano et al, 2002a; Muñoz et al, 2004).

Our results show that viral load is the main determinant of clearance and that clearance of incident infection occurs, in almost all cases, at 5 years showing no difference between viral types. This is remarkable considering possible misclassification in viral load measurements due to the semiquantitative method used in this cohort study. This method has shown moderate correlation with the real-time PCR assays that are considered more accurate (Hesselink et al, 2005). The importance of viral load as a determinant of persistence supports recent observations suggesting that $\mathrm{GP} 5+/ \mathrm{GP} 6+$ viral load is a good parameter to distinguish those HR HPV infections that will progress to CIN3 + from those that will not (Snijders et al, 2006; Gravitt et al, 2007). Our results agree with other longitudinal studies using semiquantitative and quantitative PCR assays that show that high viral load is associated with an increased risk for HSIL or CIN2/3 (Ylitalo et al, 2000; van Duin et al, 2002; Schlecht et al, 2003; Dalstein et al, 2003; Monnier-Benoit et al, 2006). However, other studies using hybrid Capture 2 viral load measurement for a pool of 13 carcinogenic HPV types have yielded negative results (Lorincz et al, 2002; Castle et al, 2004). There are at least two possible explanations for the discordant results: first, comparison between studies is difficult because results are not given in absolute measurements; second, studies using hybrid Capture 2 viral load measurement provide an additive measurement of 13 types, whereas those giving positive results provide measurement for individual types and most have focused on HPV16. Although quantitative PCR techniques provide information on the amount of viral particles in each cell and correct for differences in amplification efficiency between samples, they cannot be used in large studies because they are laborious, expensive and have been developed only for a few HPV types (HPV16, 18, 31, 33, 45 and 58). In contrast, semiquantitative assays, though they analyse the number of viral copies by scrapes and not by cells and perform less 
efficiently in an intermediate viral load range, seem to perform adequately in high viral load ranges that are clinically relevant because they are associated with an increased risk of disease. However, one limitation of our findings is that we have used the maximum viral load attained during an incident infection and little is known on the dynamics of viral load during the course of an incident infection.

The lack of differences in persistence by viral type is at odds with the results obtained in a previous analysis of the same population where only prevalent HPV infections were considered (Molano et al, 2003). HPV16 had a significantly lower clearance than LR types and HR types other than $\alpha-9$ species, and HPV types related to HPV16 had intermediate clearance rates. Such differences might be due to our restricting the analysis to incident infections in women with normal cytology at baseline and conducting a separate analysis by viral group instead of comparing between them. This approach gave us more observations to analyse and a straightforward interpretation of results as no viral type was considered as reference value.

An unexpected result was the lack of difference in the probability of clearance in women by age (under and over 30), contrary to a report from Guanacaste, Costa Rica that persistence increases with age (Castle et al, 2005). However, our results are in agreement with the lack of association between age and duration of infection recently reported from a cohort study similar to ours in Brazil (Trottier et al, 2008). Differences in study design (including the definition of persistence and inclusion of prevalent and incident HPV infections) and in statistical analysis may explain the discrepancies. In the Guanacaste study, persistence was defined as HPV DNA positivity at enrolment and at a single follow-up visit 5-7 years after enrolment, and survival analyses were not used.

We are proposing a new definition of persistence based on duration of incident infection, that is persistent infections are those lasting more than the median duration.

We believe that this definition is more informative than the traditional based on two consecutive HPV-positive tests that can be separated by irregular time intervals.

The risk pattern of CIN2/3/HSIL associated with the two definitions of persistence was remarkably similar. This is not surprising considering that our follow-up visits were separated by regular intervals of about 7 months. When persistence was defined as HPV DNA positivity at two consecutive visits, the risk was higher than when HPV DNA positivity was detected only at one of the two consecutive visits.

These results accord with those obtained in a recent meta-analysis in which persistence defined as HPV positivity at two or more time points was associated with an increased risk of $\mathrm{CIN} 2 / 3$ in most studies. However in this meta-analysis there was notable heterogeneity among the few studies that provided sufficient data to obtain HPV16 and 18 type-specific associations (Koshiol et al, 2008).

\section{REFERENCES}

Bosch FX, Burchell AN, Schiffman M, Giuliano AR, de Sanjose S, Bruni L, Tortolero-Luna G, Kjaer SK, Muñoz N (2008) Epidemiology and natural history of human papillomavirus infections and type-specific implications in cervical neoplasia. Vaccine 26(Suppl 10): K1 - K16

Brown DR, Shew ML, Qadadri B, Neptune N, Vargas M, Tu W, Juliar BE, Breen TE, Fortenberry JD (2005) A longitudinal study of genital human papillomavirus infection in a cohort of closely followed adolescent women. I Infect Dis 191: 182-192

Castle PE, Schiffman M, Herrero R, Hildesheim A, Rodriguez AC, Bratti MC, Sherman ME, Wacholder S, Tarone R, Burk RD (2005) A prospective study of age trends in cervical human papillomavirus acquisition and persistence in Guanacaste, Costa Rica. J Infect Dis 191: $1808-1816$
Our finding of an increased risk for CIN $2 / 3$ associated with HPV positivity at only one follow-up visit for $\alpha-9$ types other than HPV16 indicates that HPV infections of short duration may also increase the risk of $\mathrm{CIN} 2 / 3$ lesions or that persistence is not essential for progression to high-grade lesions.

Our results accord with recent reports that HPV type and persistence are the main determinants of progression to CIN2/3. In particular, repeat detection of HPV DNA16 is associated with extremely high cumulative risk of subsequent CIN3 + diagnosis, exceeding 30\% in some cohorts (Schiffman et al, 2007; Rodriguez et al, 2008).

Our study has several strengths, including the relatively large sample size, the broad age range covered, the low proportion of refusals, the long follow-up period, the short interval between follow-up visits (median 6.6 months), the comprehensive information collected at baseline and during follow-up on risk factors, and the use of sensitive and well-validated PCR assays for the detection of HPV DNA in a central laboratory. The main limitation of our study is the relatively small number of CIN $2 / 3$ lesions detected, which makes our risk estimates unstable.

In conclusion, in this cohort of Colombian women, viral load is the most important determinant of HPV persistence, and persistence of HPV16 infections carry a higher risk of CIN2/3. The occurrence of CIN2/3 after non-persistent $\alpha$ - 9 infections other than HPV16 suggests that such lesions are early manifestations of HPV infection and are more likely to regress. These observations have important implications in forecasting the impact of prophylactic HPV vaccines and screening programs using HPV tests.

\section{ACKNOWLEDGEMENTS}

We thank Andrea Mann at LSHTM, UK for her comments and English proofreading before submitting this paper for publication. Grant support was received from the Colombian Science Council (Colciencias); the Department of Pathology, Vrije Universiteit Medical Center, the Netherlands and from contract (no. V501) between Merck Research Laboratories and the Instituto Nacional de Cancerología, Colombia.

The Instituto Nacional de Cancerología HPV Study Group Dr Mauricio González, Dr Joaquín Luna, Dr Gilberto Martínez, Dr Edmundo Mora, Dr Gonzalo Pérez, Dr José Maria Fuentes, Dr Constanza Gómez, Dr Eva Klaus, Dr Constanza Camargo, Dr Cecilia Tobón, Dr Teodolinda Palacio, Dr Carolina Suárez and Dr Claudia Molina.

\section{Conflict of interest}

Authors do not have a commercial or other association that may pose a conflict of interest.
Castle PE, Schiffman M, Wheeler CM (2004) Hybrid capture 2 viral load and the 2-year cumulative risk of cervical intraepithelial neoplasia grade 3 or cancer. Am J Obstet Gynecol 191: $1590-1597$

Dalstein V, Riethmuller D, Pretet JL, Le Bail Carval K, Sautiere JL, Carbillet JP, Kantelip B, Schaal JP, Mougin C (2003) Persistence and load of high-risk HPV are predictors for development of high-grade cervical lesions: a longitudinal French cohort study. Int J Cancer 106: $396-403$

de Villiers EM, Fauquet C, Broker TR, Bernard HU, zur Hausen H (2004) Classification of papillomaviruses. Virology 324: 17-27

Gage JC, Hanson VW, Abbey K, Dippery S, Gardner S, Kubota J, Schiffman $\mathrm{M}$, Solomon D, Jeronimo J (2006) Number of cervical biopsies and sensitivity of colposcopy. Obstet Gynecol 108: 264-272 
Gravitt PE, Kovacic MB, Herrero R, Schiffman M, Bratti C, Hildesheim A, Morales J, Alfaro M, Sherman ME, Wacholder S, Rodriguez AC, Burk RD (2007) High load for most high risk human papillomavirus genotypes is associated with prevalent cervical cancer precursors but only HPV16 load predicts the development of incident disease. Int J Cancer 121: $2787-2793$

Hesselink AT, van den Brule AJ, Groothuismink ZM, Molano M, Berkhof J, Meijer CJ, Snijders PJ (2005) Comparison of three different PCR methods for quantifying human papillomavirus type $16 \mathrm{DNA}$ in cervical scrape specimens. J Clin Microbiol 43: $4868-4871$

Ho GY, Bierman R, Beardsley L, Chang CJ, Burk RD (1998) Natural history of cervicovaginal papillomavirus infection in young women. $N$ Engl J Med 338: $423-428$

Insinga RP, Dasbach EJ, Elbasha EH, Liaw KL, Barr E (2007) Incidence and duration of cervical human papillomavirus $6,11,16$, and 18 infections in young women: an evaluation from multiple analytic perspectives. Cancer Epidemiol Biomarkers Prev 16(4): 709-715

Jacobs MV, Snijders PJ, van den Brule AJ, Helmerhorst TJ, Meijer CJ, Walboomers JM (1997) A general primer GP5+/GP6(+)-mediated PCR-enzyme immunoassay method for rapid detection of 14 high-risk and 6 low-risk human papillomavirus genotypes in cervical scrapings. J Clin Microbiol 35: $791-795$

Koshiol J, Lindsay L, Pimenta JM, Poole C, Jenkins D, Smith JS (2008) Persistent human papillomavirus infection and cervical neoplasia: a systematic review and meta-analysis. Am J Epidemiol 168: 123-137

Lorincz AT, Castle PE, Sherman ME, Scott DR, Glass AG, Wacholder S, Rush BB, Gravitt PE, Schussler JE, Schiffman M (2002) Viral load of human papillomavirus and risk of CIN3 or cervical cancer. Lancet 360: $228-229$

Luff RD (1992) The Bethesda System for reporting cervical/vaginal cytologic diagnoses: report of the 1991 Bethesda workshop. The Bethesda System Editorial Committee. Hum Pathol 23: 719-721

Molano M, Posso H, Weiderpass E, van den Brule AJ, Ronderos M, Franceschi S, Meijer CJ, Arslan A, Muñoz N (2002a) Prevalence and determinants of HPV infection among Colombian women with normal cytology. Br J Cancer 87: $324-333$

Molano M, Van den Brule A, Plummer M, Weiderpass E, Posso H, Arslan A, Meijer CJ, Muñoz N, Franceschi S (2003) Determinants of clearance of human papillomavirus infections in Colombian women with normal cytology: a population-based, 5-year follow-up study. Am J Epidemiol 158: $486-494$

Molano $\mathrm{M}$, van den Brule AJ, Posso $\mathrm{H}$, Weiderpass $\mathrm{E}$, Ronderos $\mathrm{M}$, Franceschi S, Meijer CJ, Arslan A, Muñoz N (2002b) Low grade squamous intra-epithelial lesions and human papillomavirus infection in Colombian women. Br J Cancer 87: 1417-1421

Monnier-Benoit S, Dalstein V, Riethmuller D, Lalaoui N, Mougin C, Pretet JL (2006) Dynamics of HPV16 DNA load reflect the natural history of cervical HPV-associated lesions. J Clin Virol 35: 270-277

Moscicki AB, Hills N, Shiboski S, Powell K, Jay N, Hanson E, Miller S, Clayton L, Farhat S, Broering J, Darragh T, Palefsky J (2001) Risks for incident human papillomavirus infection and low-grade squamous intraepithelial lesion development in young females. JAMA 285: 2995-3002

Muñoz N, Bosch FX, de Sanjose S, Herrero R, Castellsague X, Shah KV, Snijders PJ, Meijer CJ (2003) Epidemiologic classification of human papillomavirus types associated with cervical cancer. $N$ Engl J Med 348: $518-527$
Muñoz N, Mendez F, Posso H, Molano M, van den Brule AJ, Ronderos M, Meijer C, Muñoz A (2004) Incidence, duration, and determinants of cervical human papillomavirus infection in a cohort of Colombian women with normal cytological results. J Infect Dis 190: 2077-2087

Rodriguez AC, Schiffman M, Herrero R, Wacholder S, Hildesheim A, Castle PE, Solomon D, Burk R (2008) Rapid clearance of human papillomavirus and implications for clinical focus on persistent infections. J Natl Cancer Inst 100: $513-517$

Schiffman M, Castle PE, Jeronimo J, Rodriguez AC, Wacholder S (2007) Human papillomavirus and cervical cancer. Lancet 370: 890-907

Schiffman M, Herrero R, Desalle R, Hildesheim A, Wacholder S, Rodriguez AC, Bratti MC, Sherman ME, Morales J, Guillen D, Alfaro M, Hutchinson M, Wright TC, Solomon D, Chen Z, Schussler J, Castle PE, Burk RD (2005) The carcinogenicity of human papillomavirus types reflects viral evolution. Virology 337: 76-84

Schiffman M, Kjaer SK (2003) Chapter 2: natural history of anogenital human papillomavirus infection and neoplasia. J Natl Cancer Inst Monogr 2003: 14-19

Schlecht NF, Platt RW, Duarte-Franco E, Costa MC, Sobrinho JP, Prado JCM, Ferenczy A, Rohan TE, Villa LL, Franco EL (2003) Human papillomavirus infection and time to progression and regression of cervical intraepithelial neoplasia. J Natl Cancer Inst 95: 1336-1343

Snijders PJ, Hogewoning CJ, Hesselink AT, Berkhof J, Voorhorst FJ, Bleeker MC, Meijer CJ (2006) Determination of viral load thresholds in cervical scrapings to rule out CIN 3 in HPV 16, 18, 31 and 33-positive women with normal cytology. Int J Cancer 119: 1102-1107

Trottier H, Mahmud S, Prado JC, Sobrinho JS, Costa MC, Rohan TE, Villa LL, Franco EL (2008) Type-specific duration of human papillomavirus infection: implications for human papillomavirus screening and vaccination. J Infect Dis 197: 1436-1447

van den Brule AJ, Pol R, Fransen-Daalmeijer N, Schouls LM, Meijer CJ, Snijders PJ (2002) GP5+/6+ PCR followed by reverse line blot analysis enables rapid and high-throughput identification of human papillomavirus genotypes. J Clin Microbiol 40: 779-787

van Duin M, Snijders PJ, Schrijnemakers HF, Voorhorst FJ, Rozendaal L, Nobbenhuis MA, van den Brule AJ, Verheijen RH, Helmerhorst TJ, Meijer CJ (2002) Human papillomavirus 16 load in normal and abnormal cervical scrapes: an indicator of CIN II/III and viral clearance. Int $J$ Cancer 98: $590-595$

Walboomers JM, Jacobs MV, Manos MM, Bosch FX, Kummer JA, Shah KV, Snijders PJ, Peto J, Meijer CJ, Muñoz N (1999) Human papillomavirus is a necessary cause of invasive cervical cancer worldwide. J Pathol 189: 12 - 19

Winer RL, Kiviat NB, Hughes JP, Adam DE, Lee SK, Kuypers JM, Koutsky LA (2005) Development and duration of human papillomavirus lesions, after initial infection. $J$ Infect Dis 191: $731-738$

Woodman CB, Collins S, Winter H, Bailey A, Ellis J, Prior P, Yates M, Rollason TP, Young LS (2001) Natural history of cervical human papillomavirus infection in young women: a longitudinal cohort study. Lancet 357: $1831-1836$

Woodman CB, Collins SI, Young LS (2007) The natural history of cervical HPV infection: unresolved issues. Nat Rev Cancer 7: 11-22

Ylitalo N, Sorensen P, Josefsson AM, Magnusson PK, Andersen PK, Ponten J, Adami HO, Gyllensten UB, Melbye M (2000) Consistent high viral load of human papillomavirus 16 and risk of cervical carcinoma in situ: a nested case-control study. Lancet 355: $2194-2198$

Zeger SL, Liang KY (1986) Longitudinal data analysis for discrete and continuous outcomes. Biometrics 42: 121 - 130 